\title{
31 Mart 2019 Yerel Seçim Sonuçları Analizi: Malatya İli Üzerine Bir Değerlendirme ${ }^{1}$
}

\author{
Hasan YILMAZ \\ Dr. Öğr. Üyesi, İnönü Üniversitesi, İktisadi İdari Bilimler Fakültesi, \\ Siyaset Bilimi ve Kamu Yönetimi Bölümü \\ hyilmaz@inonu.edu.tr \\ Orcid ID: https://orcid.org/0000-0001-9212-8084
}

\begin{abstract}
Öz
Demokratik seçim sistemlerinin uygulandığ1 ülkelerde genel ve yerel seçimler demokrasinin uygulanabilir olduğunun kanıtlarından biri ve en önemlisidir. Seçmenler genel seçimlerde yasama ve yürütme kuvvetinin üst düzey temsilcilerini belirlerken, yerel seçimlerde ise bulundukları il ve ilçe sınırlarındaki temsilcilerini belirlemektedir. Söz konusu tüm seçimler demokrasinin geliştiği ülkelerde vatandaşın siyasal alana ilgisinin artması ile birlikte önemli bir durum haline gelmektedir. Türkiye'de 2019 yılında siyasetin, ekonominin ve sosyal hayatın odaklandığ önemli gelişmelerden biri 31 Mart 2019 yerel seçimleri olmuştur. 31 Mart 2019 yerel seçimleri bazı yerlerde beklenenden farklı sonuçlanmış, bazı yerlerde ise kamuoyunun beklediği gibi gerçekleşmiştir. Özellikle büyükşehir belediye seçim sonuçları, İstanbul Büyükşehir Belediye Başkanlığı seçimlerinin 23 Haziran 2019'da yenilenmesi gibi gelişmeler, 2019 yerel seçimlerinin önemini artırmıştır. Türkiye'de bu süreçler yaşanırken Malatya ilinde büyükşehir belediye başkanlığı yarışında Cumhur İttifakı ve AK Parti adayı Selahattin Gürkan seçimi kazanmıştır. Türkiye'deki büyükşehirler arasında Konya ilinden sonra ikinci en yüksek oyu Malatya Büyükşehir Belediye Başkan adayı almıştır. Ancak Malatya'nın merkez ilçeler dâhil toplamda 13 ilçesinde alınan sonuçlar ile büyükşehir belediye başkanlığı oylamasındaki sonuçlar oldukça dikkat çekmektedir. Bu çalışmada Malatya'da 31 Mart 2019 Yerel Seçim sonuçları üzerinde bir değerlendirme yapılmıştır.
\end{abstract}

Anahtar Kelimeler: Yerel Seçim, 31 Mart 2019 Yerel Seçimleri, Malatya.

\footnotetext{
${ }^{1}$ Makale Geliş/Kabul Tarihi: 20.11.2019 / 14.03.2021

Künye Bilgisi: Yılmaz, H. (2021). 31 Mart 2019 yerel seçim sonuçları analizi: Malatya ili üzerine bir değerlendirme, Kahramanmaraş Sütçü İmam Üniversitesi Sosyal Bilimler Dergisi, 18 (1), 688-706. DOI: 10.33437/ksusbd.649072
} 


\title{
31 March 2019 Local Election Results Analysis: An Evaluation on Malatya Province
}

\begin{abstract}
In countries where democratic electoral systems are implemented, general and local elections are one of the proofs of the viability of democracy and the most important. Voters determine the high-level representatives of the legislative and executive power in general elections, and their representatives in local elections at the borders of their provinces and districts. All the elections in question become an important situation with the increase in the interest of citizens in the political field in countries where democracy is developing. Politics in Turkey in 2019, one of the most important developments has been the focus of the economic and social life of the local elections on March 31, 2019. The local elections on March 31, 2019, were concluded differently than expected in some places, and in some places, they were realized as expected by the public. In particular, developments such as the metropolitan municipal election results and the renewal of the Istanbul Metropolitan Municipality elections on June 23, 2019, have increased the importance of the 2019 local elections. Turkey in this process was taking place in the province of Malatya metropolitan Cumhur Alliance and the AK Party candidate in the mayoral race was won Selahattin Gürkan choice. then the second-highest number of votes from among the metropolitan city of Konya in Turkey, Malatya Mayor candidate has received. However, the results obtained in 13 districts in total including the central districts of Malatya and the results of the voting for the metropolitan mayor draw attention. In this study, an evaluation was made on the results of the 31 March 2019 Local Election in Malatya.
\end{abstract}

Keywords: Local Election, March 31, 2019 Local Elections, Malatya.

\section{GİRIŞ}

Halka iktidarı belirleme yetkisinin, seçimler yoluyla verilmesi, temsili demokrasilerin en önemli özelliğidir. Siyasi partiler temsili demokrasinin önemli bir aracı olarak siyasette yer alarak seçimlere katılmaktadırlar. Seçmenler siyasi partiler yoluyla kendilerine ait düşünce, görüş, yaşayış ve inanç durumlarını temsil etme durumunda kalmaktadır.

Malatya Belediyesi Mart 2014 seçimleri ile fiilen büyükşehir statüsüne girmiştir. Mart 2014 seçimlerini Adalet ve Kalkınma Partisi (AK Parti) adayı Ahmet Çakır'ın kazanması sonucu ilk büyükşehir belediye başkanı da 
belirlenmiştir. 31 Mart 2019'a kadar geçen sürede parlamento seçimleri nedeniyle belediye başkanlığı el değiştirmiştir. Haziran 2018'de yapılan Milletvekilliği Genel Seçimleri sonucu mevcut başkan Ahmet Çakır, milletvekili seçilmesi sebebiyle belediye başkanlığı görevinden ayrılmıştır. Malatya Büyükşehir Belediye Meclisi'nde yapılan oylama sonucu Yeşilyurt Belediye Başkanı olan Hacı Uğur Polat Malatya Büyükşehir Belediye Başkanlığına seçilmiştir. Meclis toplantısında 47 meclis üyesinin 40'ının oyunu alarak seçilen (Anadolu Ajansı, 2018) Hacı Uğur Polat yaklaşık 10 ay kadar başkanlık görevini yerine getirmiştir.

Malatya'daki yerel siyaseti ve aktörlerini ele aldığımızda; siyasetin kendi doğasında var olan özelliklerin yaşadığımız döneme ait bir tezahürünü görmekteyiz. Sonuçlar kimi dönem değişse de konjoktürel gelişmeler, seçim çalışmaları, aday seçimi gibi esaslar her zaman etkisini ve güncelliğini korumaktadır. Malatya ilinde 31 Mart 2019 tarihinde yapılan yerel seçimde alınan bazı sonuçlar değişen siyasetin farklı sonuçları olduğunun göstergesi olarak analiz edilebilir.

\section{TÜRKIYE'DE SEÇMEN DAVRANIŞI ÜZERINE}

Bir toplumun geleceği önceden belirlenemez, çünkü bazı dış etkenler etkili olmaktadır. Ancak, geçmiş yaşamın incelenmesi toplumun geleceği hakkında fikir sahibi olmamızı sağlamaktadır (Ahmad, 2012: 249). Bu noktadan hareketle seçmenin gelecekte neler yapacağını söylemek zor olsa da geçmişte yaptıkları ve bugünkü izlenimleri hakkında değerlendirmeler yapmak mümkündür.

Demokrasilerde yönetimin kime, nasıl emanet edileceği tartışması, yaşanan mücadeleler sonucunda, iktidarı belirleyecek yetkinin halka verilmesi ile sonuçlanmıştır. Siyasal ve toplumsal düzeyde meşruiyet kaynağı böylelikle değişime uğramıştır (Sartori, 1996: 31). Demokrasilerin en temel sorunlarından biri olan katılım sorunu uygulamada temsili demokrasi anlayışına zemin hazırlamıştır. Demokrasilerde halkın tekelinde olan yönetim hakkı, temsili demokrasilerde seçimler aracıllğıyla temsilcilere aktarılarak sağlanmaktadır. Seçimler yoluyla halkı temsil hakkını kazanan iktidar, böylelikle meşruiyet sorununu ortadan kaldırmaktadır (Çam, 2002: 481). Halkın temsil hakkını kazanmak bir hayli zor süreçtir. Seçmen kitlesini etkileyebilmek ve inandırabilmek gereklidir. Böylelikle seçmenin davranış özellikleri belirginleşir ve ortaya davranış modelleri çıkmaktadır.

Marius Deeb, siyasal partilerin önemi ve özelliklerini kavramak için üç temel belirleyici faktör olduğundan bahsetmektedir. Bu temel belirleyici faktörler; parti ve siyasetçinin ilkeleri, kurumsal yapısı veya örgüt şekli ile toplumsal temelidir (aktaran Zürcher, 1992: 9). Buna göre belki de seçmenler ilk olarak, siyasi parti ve siyasetçilerin önemini kavrayabilmek adına girişimlerde bulunmalıdır. 
Girişimler sonucunda ilkesi, yapısı ve toplumsal temeli belirlenmiş bir siyasal alanı kabul eden ve buna uygun seçmen davranışında bulunan kitleler görülecektir. Böylelikle seçmen davranışlarının analizi nesnel olarak yapılabilecektir.

Seçmen davranışı yerel idareler seçimleri özelinde incelendiğinde üç temel faktör ortaya çıkmaktadır. Birincisi; seçmen partilerle olan bağlarını güçlü tutmaktadır. Genel veya yerel seçim ayrımı yapmadan seçmen partisini önceden belirlemektedir. İkincisi, seçmen ekonomik yapıya dikkat etmektedir. Belediyelerin harcama politikaları, başkanların siyasi geleceklerini belirlemektedir. Üçüncü olarak etnik ve kültürel farklılıklar, kimi partilerin siyaset yapma şekillerine göre bazı illerde öne çıkarmaktadır (Akgün, 2007: 110). Yerel seçim özelinde ortaya çıkan bu farklılıklar seçilen adayın kaderini de belirlemektedir. $\mathrm{Bu}$ süreç ise demokrasi yaşamını doğrudan veya dolaylı etkilemektedir.

Seçmenlerin ekonomik tercihlerde bulunması yaklaşımı, kişinin herhangi kişisel görüş etkisinde kalmadan, başka birini kırmama düşüncesinde hareketle bir partiye oy vermesinin söz konusu olmaması olarak kabul edilmektedir. Bu bağlamda seçmen siyasi amaçları üzerinde odaklanarak sosyo-psikolojik modelden farkl1 bir konuma gelmektedir (Harrop ve Miller, 1987: 145).

Demokrasilerde içsellik ve kurumsallık sorunu seçmeni etkileyen diğer önemli bir faktördür. Bu bağlamda katılımcı demokrasi anlayışı ile sivil topluma gereken önemin verilmesi, demokrasinin içselliği ve kurumsallığına olumlu etki etmektedir. Halkın yönetime aktif olarak katılması ile siyasal alanda önemli bir sorun giderilebilecektir (Akınc1 ve Usta, 2015: 51).

Seçmen davranışı üzerine yapılan teorik çalışmaların yanı sıra alan araştırmaları şunu göstermiştir ki; seçmenler özellikle yerel seçimlerde aile, arkadaş ve kanaat önderi gibi yakın çevresinden etkilenmektedir. Bu etkilenmede ve seçmen tercihini belirlemede, yerel değişkenler ve siyasal iletişim faaliyetleri öne çıkmaktadır (Doğan ve Göker, 2010: 184).

\section{MALATYA İLİ 31 MART 2019 YEREL SEÇIME KATILIM DURUMU}

Malatya ilinde gerçekleşen 31 Mart 2019 Yerel Seçimlerinde seçime katılım ile ilgili bilgiler dikkat çekmektedir. Tablo 2'de Malatya ilinde 2014 ve 2019 yıllarında yapılan yerel seçimlerine ait seçim sonuçları bilgileri yer almaktadır. Bu tabloda; büyükşehir ve ilçe belediye başkanlıkları ile birlikte belediye meclis üyeliği seçimlerine ait genel bilgiler yer almaktadır. 
Tablo 1. 2014 ve 2019 Malatya Yerel Seçimlerine Katılım Oranları

\begin{tabular}{|l|l|l|l|l|l|l|}
\hline & \multicolumn{4}{|l|}{$\mathbf{2 0 1 4}$ Yerel Seçimi } & \multicolumn{2}{l|}{$\mathbf{2 0 1 9}$ Yerel Seçimi } \\
\cline { 2 - 7 } & $\mathbf{B S ̧}^{\mathbf{2}}$ & İlçe & $\mathbf{B M}^{\mathbf{3}}$ & $\mathbf{B S ̧}$ & İlçe & BM \\
\hline $\begin{array}{l}\text { Kayıtlı } \\
\text { Seçmen }\end{array}$ & 524.212 & 524.212 & 524.212 & 561.708 & 561.708 & 561.708 \\
\hline $\begin{array}{l}\text { Oy Kullanan } \\
\text { Seçmen }\end{array}$ & 457.515 & 456.463 & 456.265 & 464.819 & 464.107 & 463.826 \\
\hline Geçerli Oy & 444.973 & 442.935 & 442.014 & 446.292 & 444.288 & 442.218 \\
\hline Geçersiz Oy & 12.542 & 13.528 & 14.251 & 18.527 & 19.819 & 21.608 \\
\hline Katılım (\%) & 87.28 & 87.08 & 87.04 & 82.75 & 82.62 & 82.57 \\
\hline
\end{tabular}

Kaynak: YSK'nın 2019 yılı verilerine göre yazar tarafından derlenmiştir.

Tablodan çıkarılacak ilk sonuçlardan biri; oy kullanan seçmen sayısı artarken geçerli oyların aynı oranla artmadığıdır. 2019 seçimlerinde büyükşehir ve belediye meclisi kıyaslamasında geçerli oylar arasında yaklaşık dört bin oy farkı bulunmaktadir.

Tablodan çıkarılacak analizlerin başında oransal olarak iki seçim arasındaki farklar göze çarpmaktadır. İki seçime ait veriler incelediğinde 2019 seçimlerine katılım oran1 2014 seçimlerine göre yaklaş1k \%5 düşüş göstermiştir. Bu düşüşün sebepleri arasında ekonomik sorunlar, siyasi ve ideolojik yaklaşımlar ve yerelde yaşanan gelişmeler olduğu söylenebilir.

Tablodan çıkarılacak bir başka sonuç ise geçersiz oylardaki artıştır. 31 Mart 2019 seçimlerinde büyükşsehir adaylığı oyları ile belediye meclis üyeliği adaylığ1 arasında yaklaşık üç bin oy farkı bulunmaktadır. Bu fark sayısal olarak 561.708 seçmen içinde önemli bir fark olarak görülmese de siyasi bir seçmen mesajı olarak görülebilir. Büyükşehir adayına olan ilgi veya belediye meclis üyeliği adaylarına tepki olabileceği düşünülebilir. Diğer yandan büyükşehir adaylarının ittifaklar üzerinden belirlenmesi ve bu sürecin oluşturduğu sonuç olarak da değerlendirilebilir. Diğer bir açıdan ittifak adaylarının ittifak içerisinde tepkisel oylarının yansıması olarak da görülebilir.

\section{MALATYA 2019 YEREL SEÇIM SONUÇLARI}

Malatya 2019 yerel seçimlerinin en belirgin sonucu kuşkusuz resmi olarak AK Parti ve Milliyetçi Hareket Partisi'nden (MHP) oluşan Cumhur İttifakının aldığı sonuçtur. AK Parti'nin kuruluşundan itibaren katıldığı seçimlerde en yüksek oy oranlarına ulaştığı Malatya'da 31 Mart 2019 yerel seçimleri AK Parti ve Cumhur İttifakı açısından başarı olarak kabul edilebilir. Türkiye'de büyükşehirler

${ }^{2}$ Büyükşehir belediye başkanlığı seçimi

${ }^{3}$ Belediye meclis üyeliği seçimi 
arasında Konya'dan sonra ikinci en yüksek oyu alarak önemli bir başarı yakalanmıştır. Malatya ilinde yapılan yerel seçimlerde büyükşehir belediyesi ve on üç ilçe belediyesinde başkanlık seçimi yapılmıştır. Cumhur İttifakı büyükşehir dâhil toplamda on belediye başkanlığı kazanmıştır. Kalan dört başkanlığın üçünü Millet İttifakı, birini ise bağımsız aday kazanmıştır (YSK, 2019).

Tablo 2. 31 Mart 2019 Malatya İli Seçim Sonuçları

\begin{tabular}{|c|c|c|c|c|c|c|c|c|c|c|c|}
\hline & $\begin{array}{l}\text { B. } \\
\text { Başkanı }\end{array}$ & Belediye & İlçe B & elediye & Başkan & & & Beled & iye Mecli & is Üyes & \\
\hline |̇leçeler & 恶 & 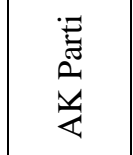 & 恶 & $\begin{array}{l}:= \\
\tilde{z} \\
a \\
\underline{z}\end{array}$ & 政 & 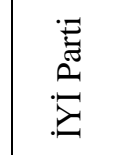 & 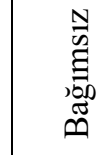 & 蒠 & 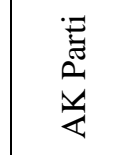 & 茎 & 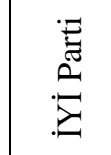 \\
\hline Akçadağ & 7465 & 14.482 & 7818 & 7.195 & 0 & 0 & 8055 & 7185 & 9289 & 0 & 0 \\
\hline Arapgir & 3081 & 3871 & 3793 & 3.025 & 0 & 0 & 0 & 3708 & 3056 & 0 & 0 \\
\hline \begin{tabular}{|l|} 
Arguvan \\
\end{tabular} & 3283 & 1720 & 2899 & 917 & 0 & 0 & 0 & 2862 & 1159 & 0 & 0 \\
\hline Battalgazi & 24.868 & $\mid 117.259$ & 0 & $\begin{array}{l}108.56 \\
8\end{array}$ & 0 & 35.535 & 0 & 0 & 110.303 & 0 & 29.390 \\
\hline Darende & 2079 & 14.538 & 0 & 8823 & 0 & 0 & 0 & 0 & 9451 & 0 & 665 \\
\hline Doğanşehir & 10.335 & 14.003 & $\begin{array}{l}11.61 \\
6\end{array}$ & 13.130 & 0 & 0 & 0 & $\begin{array}{l}11.45 \\
0\end{array}$ & 12.947 & 0 & 0 \\
\hline Doğanyol & 236 & 2035 & 123 & 1468 & 0 & 0 & 0 & 173 & 1420 & 0 & 0 \\
\hline Hekimhan & 7712 & 7966 & 8123 & 0 & 7680 & 0 & 0 & 7946 & 0 & 7526 & 0 \\
\hline Kale & 217 & 3473 & 0 & 2196 & 0 & 16 & 0 & 0 & 2325 & 0 & 29 \\
\hline Kuluncak & 1821 & 4117 & 2300 & 0 & 2778 & 0 & 425 & 2311 & 0 & 2781 & 0 \\
\hline Pütürge & 535 & 6989 & 0 & 5431 & 0 & 0 & 0 & 0 & 5530 & 0 & 0 \\
\hline Yazıhan & 2912 & 7469 & 3477 & 6950 & 0 & 0 & 0 & 3346 & 6837 & 0 & 0 \\
\hline Yeşilyurt & 39.126 & 107.666 & $\begin{array}{l}34.39 \\
8 \\
\end{array}$ & $\begin{array}{l}102.57 \\
0\end{array}$ & 0 & 10.690 & 0 & $\begin{array}{l}35.98 \\
1 \\
\end{array}$ & 101.505 & 0 & 9145 \\
\hline TOPLAM & 103.690 & 305.588 & $\begin{array}{l}74.54 \\
7 \\
\end{array}$ & \begin{tabular}{|l|}
260.27 \\
3
\end{tabular} & 10.458 & 46.241 & & \begin{tabular}{|l}
74.96 \\
2
\end{tabular} & 263.822 & $\begin{array}{l}10.30 \\
7\end{array}$ & 39.229 \\
\hline
\end{tabular}

Kaynak: 2019 YSK verilerine göre yazar tarafından derlenmiştir.

Cumhur İttifakı üyesi MHP, büyükşehir belediye başkanı adayı çıkarmamış AK Parti adayını desteklemiştir. MHP diğer yandan Hekimhan ve Kuluncak ilçelerinde aday çıkarmış, Hekimhan'da başkanlık yarışını kaybederken, Kuluncak'ta kazanmıştır. Cumhur İttifakı büyükşsehirden ayrı olmak üzere dokuz ilçede seçim yarışını kazanmıştır. Battalgazi ve Yeşilyurt merkez ilçeleri ile birlikte Darende, Doğanşehir, Doğanyol, Kale, Kuluncak, Pütürge, Yazıhan ilçelerinde belediye başkanlığını kazanmıştır. Diğer yandan belediye meclis üyelik seçimlerinde merkez ilçeler dâhil dokuz ilçede AK Parti, üç ilçede CHP, bir ilçede MHP en fazla üye sayısına sahip olmuştur. Tablo 1'den anlaşılacağı 
üzere büyükşehirde yarışı kazanan Cumhur İttifakı, merkez ilçeler dâhil dokuz ilçede başkanlığı kazanmıştır. Millet İttifakı ise üç ilçede seçim yarışını kazanmış, bir ilçede ise bağımsız aday kazanmıştır. Sonuçlara göre Cumhur İttifakı'nın oy sayısı, oy oranları ve kazandığı başkanlık sayısı bakımından üstünlük kurduğu görülmektedir.

\section{Malatya İli Büyükşehir Belediye Başkanlığı Seçim Sonuçları}

31 Mart 2019 seçim sonuçlarına göre Cumhur İttifakı ve AK Parti Büyükşehir Belediye Başkan adayı Selahattin Gürkan geçerli oyların en fazlasını alarak Malatya Büyükşsehir Belediye Başkanı olmuştur.

Tablo 3. Malatya Büyükşehir Belediye Başkanlığı Sonuçları

\begin{tabular}{|l|l|l|l|}
\hline Parti & Aday & Aldı̆̆ Oy & Oran (\%) \\
\hline AK Parti & Selahattin Gürkan & 305.588 & 68.47 \\
\hline CHP & Soner Gökçe & 103.690 & 23.23 \\
\hline Saadet Partisi & Osman Cemali Marasalı & 23.682 & 5.31 \\
\hline HDP & Yusuf Bozkuş & 6555 & 1.47 \\
\hline DP & Mehmet Cahit Karakuş & 1651 & 0.37 \\
\hline BTP & Mesut Günışı & 1508 & 0.34 \\
\hline DSP & Haydar Levent & 1345 & 0.30 \\
\hline Bağımsız & Şerif Demirel & 1029 & 0.23 \\
\hline TKP & Ferhat Tunçdemir & 626 & 0.14 \\
\hline Vatan Partisi & Hüseyin Koç & 0.14 \\
\hline IYİ Parti & Aday Çıkarmamıştır & \\
\hline BBP & Aday Çıkarmamıştır & \\
\hline MHP & Aday Çıkarmamıştır & \\
\hline Kaynak: & \multicolumn{2}{|l}{} \\
\hline
\end{tabular}

Kaynak: 2019 YSK verilerine göre yazar tarafindan derlenmiştir.

Tablo 3'e göre Malatya Büyükşehir Belediye Başkanlığı seçimlerinde ittifaklar öne çıkmıştır. AK Parti ve MHP'nin Cumhur İttifakı, aday olarak Selahattin Gürkan'ı belirlerken, Millet İttifakı CHP ve İYİ Parti, Avukat Soner Gökçe ile seçime katılmıştır.

Malatya ilinde büyükşehir yarışında ittifaklar dışında en güçlü adaylardan biri Saadet Partisi adayı Osman Cemali Marasalı olmuştur. Adaylık öncesi Saadet Partisi İl Başkanlığı'nı yürüten Marasalı, seçimde 25 bine yakın oy almıştır. İttifak adayları ve Osman Cemali Marasalı haricinde diğer adaylardan öne çıkan olmadığı söylenebilir.

Diğer yandan bu seçimde, resmi olarak ittifakta yer almasa da BBP'nin, Türkiye genelinde aday çıkarmayacağı ve Cumhur İttifakı'na destek vereceği 
bilinmektedir. BBP Genel Başkanı Mustafa Destici seçim öncesi ve sonrası yaptığı açıklamalarda Cumhur İttifakı'nda pazarlık yapmadıklarını ancak desteklediklerini belirtmiştir. Özellikle İstanbul seçimlerinin yenilenmesinde Cumhur İttifakının zaferi kazanacağına dair beyanları bulunmaktadır (BBP, 2019). Ancak Malatya'da on üç ilçenin altısında aday göstermesi ve özellikle Darende ilçesinde seçim yarışına Hamit Demir ile katılarak Cumhur İttifakını seçimde zorlaması dikkat çekmektedir. BBP adayı Darende'de seçimi kazanan Cumhur İttifakı adayından yaklaşık üç yüz oy az alarak toplamda 8.500 civarında oy almış ve seçim ittifakı açıklamalarının tersi bir durum yaşanmıştır.

Yerel seçimlerde sonuçların seçmen davranışı üzerinden değerlendirilmesi oldukça önemli ve bir o kadar karmaşık bir durumdur. İllerin farklı sosyal ve siyasal yapılarından kaynaklandığı düşünülen bu durum, esasen toplumdaki yerel aktörlerin öne çıkmasına zemin hazırlamaktadır. Yereldeki aktörlerin siyaset açısından kazandığ 1 teveccüh siyasal pazarlama kavramı ile ilgilidir. İlk olarak 1950'li yıllarda ortaya çıktığı belirtilen adayı potansiyel seçmenlere tanıtmak, seçimde rakiplerini geçmesini sağlamak, asgari düzeyde araçlarla seçimi kazanabilmek (Demirtaş ve Orçun, 2015: 42) anlamına gelen siyasal pazarlama, günümüzde oldukça önemli bir kavram haline gelmiştir. 31 Mart 2019 yerel seçimleri siyasal pazarlama açısından değerlendirildiğinde Malatya ili seçim sonuçlarının farkı ortaya çıkmaktadır.

Selahattin Gürkan seçim çalışması kapsamında katıldığı bir programda 31 Mart seçimlerini seçim olarak görmediğini, bayram olarak gördügünü söylemiştir. Malatya'da artık her kesim, düşünce ve ideolojinin bir olduğunu ve böylelikle hep birlikte Malatya'nın oluşacağını vurgulamıştır (Habertürk, 2019). Tüm kesimleri kucaklayacağı anlamına gelen ve sıklıkla bu durumu ifade eden Gürkan, ideoloji ve grupsal ayrılıkları bir tarafa bırakmak gerektiğini beyan ederken parti ve ittifak üstü bir söyleme de imza atmaktadır. Söz konusu söylemlerin arkasında Cumhur İttifakı'nın yer aldığı düşünülebilir, bir başka açıdan ise Gürkan'ın partiler üstü bir siyaset tarzı ile yerel siyasi aktör olabilme düşüncesi yer alabilir.

Tablo 4. Malatya Büyükşehir Belediye Başkan Adaylarının İlçelerden Aldıkları Oyların Dağılımı

\begin{tabular}{|c|c|c|c|c|c|c|c|c|c|c|}
\hline Ilçe & के & 苗 & 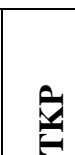 & 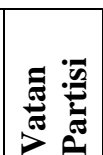 & $\underline{\mathbf{J}}$ & 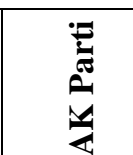 & คิ & 宣 & के & نّ. \\
\hline Akçadağ & 767 & 224 & 42 & 32 & 7465 & 14.482 & 28 & 598 & 32 & 419 \\
\hline Arapgir & 173 & 21 & 7 & 9 & 3081 & 3871 & 10 & 52 & 3 & 6 \\
\hline Arguvan & 43 & 5 & 17 & 11 & 3283 & 1720 & 30 & 440 & 625 & 3 \\
\hline Battalgazi & 9195 & 368 & 196 & 244 & 24.868 & 117.259 & 330 & 2320 & 242 & 212 \\
\hline
\end{tabular}




\begin{tabular}{|l|l|l|l|l|l|l|l|l|l|l|}
\hline Darende & 592 & 146 & 33 & 32 & 2079 & 14.538 & 27 & 152 & 28 & 6 \\
\hline Doğanşehir & 552 & 29 & 23 & 32 & 10.355 & 14.003 & 44 & 364 & 23 & 29 \\
\hline Doğanyol & 116 & 2 & 1 & 4 & 236 & 2035 & 368 & 13 & 14 & 2 \\
\hline Hekimhan & 271 & 13 & 22 & 35 & 7712 & 7966 & 29 & 51 & 30 & 13 \\
\hline Kale & 123 & 26 & 9 & 0 & 217 & 3473 & 272 & 9 & 8 & 0 \\
\hline Kuluncak & 174 & 35 & 11 & 7 & 1821 & 4117 & 13 & 23 & 9 & 10 \\
\hline Pütürge & 1603 & 16 & 4 & 4 & 535 & 6989 & 21 & 31 & 6 & 2 \\
\hline Yazıhan & 260 & 18 & 8 & 7 & 2912 & 7469 & 11 & 359 & 13 & 2 \\
\hline Yeşilyurt & 9840 & 579 & 252 & 201 & 39.126 & 107.666 & 468 & 2143 & 312 & 325 \\
\hline TOPLAM & $\mathbf{2 3 . 7 0 9}$ & $\mathbf{1 4 8 2}$ & $\mathbf{6 2 5}$ & $\mathbf{6 1 8}$ & $\mathbf{1 0 3 . 6 9 0}$ & $\mathbf{3 0 5 . 5 8 8}$ & $\mathbf{1 6 5 1}$ & $\mathbf{6 5 5 5}$ & $\mathbf{1 3 4 5}$ & $\mathbf{1 0 2 9}$ \\
\hline
\end{tabular}

Kaynak: 2019 YSK verilerine göre yazar tarafından derlenmiştir.

Selahattin Gürkan katıldığ 1 bir programda ise, 31 Mart seçimlerinin çok önemli olduğunu ve herkesin sandığa gitmesi gerektiğini belirtmiştir. Üç dönemdir belediye başkanlığı yaptığını ve ilk defa oy istediğini beyan etmiştir. Şimdiye kadar hangi parti, görüş ve düşünceye sahip olursa olsun bu seçimde AK Parti'yi seçmelerini arzu ettiğini dile getirmiştir (Vuslat, 2019). 2004'te bağımsız aday olarak başkan seçilen, 2009 ve 2014 yıllarında AK Parti'den Battalgazi Belediye Başkanı olan Selahattin Gürkan'ın "ilk defa oy istiyorum" açıklaması seçimlere damga vurmuştur.

Tablo 4'e göre Selahattin Gürkan Arguvan dışındaki ilçelerde ilçe belediye başkan adaylarından daha fazla oy almıştır. Arguvan'da Soner Gökçe'ye verilen oylar Selahattin Gürkan'a verilen oyların yaklaşık iki katı kadardır. Selahattin Gürkan diğer yandan Millet İttifakının kazandığı Arapgir'de ve Hekimhan'da daha fazla oy alabilmiştir. Ancak Millet İttifakının kazandığı üç ilçenin sadece birinde Selahattin Gürkan'ın geride kalması seçmen davranışı ile ilgili önemli bir sonuçtur. Cumhur İttifakının kaybettiği ve bağımsız adayın kazandı̆̆ Akçadağ ilçesinde; Selahattin Gürkan, CHP oylarının yaklaşık iki katı kadar oy almıştır.

\section{Malatya İli 2019 İlçe Belediye Başkanlıkları Seçim Sonuçları}

Malatya ilinde büyükşehir belediye başkanlığı haricinde, merkez ilçeler Yeşilyurt ve Battalgazi dâhil toplam 13 belediye başkanı seçimi yapılmıştır. $\mathrm{Bu}$ seçimlerde Cumhur ittifakı dokuz, Millet İttifakı üç belediye başkanlı̆̆ 1 kazanırken bir ilçede bağımsız aday başkan olarak seçilmiştir.

Tablo 5. Malatya İlçe Belediye Başkanlık Seçimi Oy Dağılımı

\begin{tabular}{|c|c|c|c|c|c|c|c|c|c|c|c|c|}
\hline İlçe & के & 苜 & $\vec{z}$ & $\hat{\text { ติ }}$ & 言 & 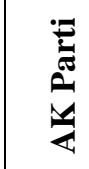 & ดิ & $\hat{\Sigma}$ & 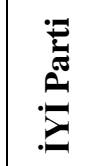 & 空 & ڤิ & ڤ્. \\
\hline \begin{tabular}{|l} 
Akçadağ \\
\end{tabular} & 166 & 572 & 0 & 0 & 7818 & 7195 & 0 & 0 & 0 & 0 & 0 & 8055 \\
\hline
\end{tabular}




\begin{tabular}{|l|l|l|l|l|l|l|l|l|l|l|l|l|}
\hline Arapgir & 35 & 21 & 0 & 291 & 3793 & 3025 & 0 & 0 & 0 & 0 & 0 & 0 \\
\hline Arguvan & 18 & 1 & 6 & 0 & 2899 & 917 & 0 & 0 & 0 & 414 & 1853 & 0 \\
\hline Battalgazi & 4310 & 440 & 0 & 2623 & 0 & $\begin{array}{l}108.56 \\
8\end{array}$ & 0 & 0 & $\begin{array}{l}35.53 \\
5\end{array}$ & 3051 & 0 & 0 \\
\hline Darende & 195 & 230 & 0 & 8542 & 0 & 8823 & 0 & 0 & 0 & 0 & 0 & 0 \\
\hline Doğanşehir & 307 & 57 & 0 & 0 & 11.616 & 13.130 & 0 & 0 & 0 & 0 & 0 & 0 \\
\hline Doğanyol & 27 & 5 & 0 & 0 & 123 & 1468 & $\begin{array}{l}117 \\
2\end{array}$ & 0 & 0 & 0 & 0 & 0 \\
\hline Hekimhan & 132 & 25 & 48 & 0 & 8123 & 0 & 0 & 7680 & 0 & 0 & 0 & 0 \\
\hline Kale & 20 & 24 & 0 & 783 & 0 & 2196 & $\begin{array}{l}105 \\
5\end{array}$ & 0 & 16 & 0 & 0 & 0 \\
\hline Kuluncak & 0 & 42 & 0 & 652 & 2300 & 0 & 0 & 2778 & 0 & 0 & 10 & 425 \\
\hline Pütürge & 3596 & 52 & 0 & 0 & 0 & 5431 & 0 & 0 & 0 & 0 & 0 & 0 \\
\hline Yazıhan & 125 & 21 & 0 & 0 & 3477 & 6950 & 0 & 0 & 0 & 280 & 0 & 0 \\
\hline Yeşilyurt & 8611 & 418 & 0 & 3492 & 34.398 & $\begin{array}{l}102.57 \\
0\end{array}$ & 567 & 0 & $\begin{array}{l}10.69 \\
0\end{array}$ & 0 & 0 & 0 \\
\hline TOPLAM & $\begin{array}{l}\mathbf{1 7 . 5 4} \\
\mathbf{2}\end{array}$ & $\mathbf{1 9 0 8}$ & $\mathbf{5 4}$ & $\mathbf{1 6 . 3 8 3}$ & $\mathbf{7 4 . 5 4 7}$ & $\begin{array}{l}\mathbf{2 6 0 . 2 7} \\
\mathbf{3}\end{array}$ & $\begin{array}{l}\mathbf{2 7 9} \\
\mathbf{4}\end{array}$ & $\begin{array}{l}\mathbf{1 0 . 4 5} \\
\mathbf{8}\end{array}$ & $\mathbf{4 6 . 2 4}$ \\
$\mathbf{1}$ & $\mathbf{3 7 4 5}$ & $\mathbf{1 8 6 3}$ & $\mathbf{8 4 8 0}$ \\
\hline
\end{tabular}

Kaynak: 2019 YSK verilerine göre yazar tarafindan derlenmiştir.

Merkez ilçelerden biri olan Battalgazi İlçesinde AK Parti ilçe belediye başkan adayı Osman Güder 108.568 oy alarak seçimi kazanmıştır. AK Parti Büyükşehir Belediye Başkan adayı Selahattin Gürkan bu ilçeden 117.259 oy almıştır. Büyükşehir adayı ve ilçe adayı arasındaki 8.691 oyun Millet İttifakı cephesinden veya diğer partilerden geldiği düşünülebilir. Şöyle ki; İlçede Millet İttifakı (CHPİYİ Parti) adayı Ali Ekinci'ye verilen oyların bir kısmı, büyükşehirde Cumhur İttifakı adayına gelmiş olabilir.

AK Parti'de 2019 yerel seçimleri için belediye başkan aday adaylığına başvuran ve 2014 yerel seçimlerinde seçim yarışına bağımsız olarak girip AK Parti'nin ardından ikinci en yüksek oyu alan Ali Ekinci'nin, ilçe seçmeninden aldığı oy önemli bir gelişme olmuştur. Millet İttifakı cephesinden bakıldığında İYI Parti adayı olarak 35.535 oy ile ilçedeki en yüksek ikinci oyu alması ve Battalgazi seçmeninden Millet İttifakı Büyükşehir Belediye Başkan adayı Soner Gökçe'ye verilen oylardan 10.667 daha fazla alması önemli bir gösterge olmuştur. Soner Gökçe büyükş̧ehir belediye başkanı adayı olarak girdiği yarışta Battalgazi seçmeninden 24.868 oy alabilmiştir.

Malatya'nın bir diğer merkez ilçesi olan Yeşilyurt ilçesinde Cumhur İttifakı adayı Mehmet Çınar seçim yarışını kazanmıştır. Yeşilyurt ilçesinde Millet İttifakı resmi olarak oluşturulmamış ve seçimde CHP adayı Erkan Özgür 34.398, IYYI Parti adayı Cem Parlak 10.690 oy almıştır. Rakamlara bakıldığında Millet ittifakının resmi olmasa da 45 bin civarında oy toplamına ulaştığı söylenebilir. Ancak Yeşilyurt ilçesinde Millet İttifakı Büyükşehir Belediye Başkan adayı 
olarak gösterilen Soner Gökçe 39.126 oy almıştır. Bu sonuca göre Millet İttifakının yaklaşık 6 bin oyunun Büyükşehir belediye başkanlığı seçimlerinde diğer adaylara dağıldığı veya doğrudan Selahattin Gürkan'a geçtiği söylenebilir.

Akçadağ ilçesinde 2014 yerel seçimlerinde AK Parti'den Belediye Başkanı olarak seçilen Ali Kazgan ise bağımsız aday olarak girdiği 2019 seçimlerini 8.055 oy alarak kazanmıştır. AK Parti Belediye Başkan adayı Mustafa Kırteke 7.195 oy alırken, Büyükşehir Belediye Başkanlı̆̆ı oylamasında Selahattin Gürkan, Kırteke'den yaklaşık iki kat fazla oy almıştır. Akçadağ'da Cumhur İttifakı büyükşehir adayı Selahattin Gürkan'a 3.871 oy verilmiştir. Bu sonuçlara göre Akçadağ ilçesinde aday isimlerinin öne çıktığı görülmektedir. Akçadağ seçmeni ilçesinde bağımsız adaya en fazla oyu verirken büyükşehirde Cumhur İttifakına oy kullanmıştır. Diğer yandan Selahattin Gürkan ilçedeki seçimi kazanan bağımsız adaydan daha fazla oy alabilmiştir.

Arapgir'de Millet İttifakı ve CHP adayı Haluk Cömertoğlu 3.081 oy alarak kazanmıştır. Oysaki Haluk Cömertoğlu 2014 seçimlerinde AK Parti adayı olarak girdiği seçimde 3.288 oy almıştı (Habertürk, 2014). Buradan hareketle seçmen sayısı artmasına rağmen ilçeden aldığı oylar 2014 'de aldığ 1 oy sayısına göre azalmış denilebilir. Arapgir ilçesinde Cumhur ittifakı adayı Rıza Murat Türksoy 3.025 oyda kalmıştır. Ancak bir önceki dönem AK Parti Belediye Başkanı olarak görev yapan Haluk Cömertoğlu'nun CHP'den aday olması yerel seçmende sonucu etkileyebilecek dozda bir tepki oluşturmamıştır. Bu ilçede aday isminin ön plana çıktığı veya tepkisel oyların öne çıktığı değerlendirmeleri yapılabilir.

Arguvan'da seçimi 2.899 oy alan Millet İttifakı ve CHP adayı Mehmet Kızıldaş kazanmıştır. İkinci en yüksek oyu DSP adayı Ergün Kılıç almıştır. Cumhur ittifakı ve AK Parti adayı Ahmet Eren 917 oyda kalmıştır. Cumhur ittifak1 Büyükşehir belediye başkanlığı oylamasında Selahattin Gürkan 1.720 oy almıştır. Cumhur ittifakının ilçe bazında büyükşehir oyları, ilçe oylarının yaklaşık iki katı kadardır.

Darende ilçesinde Cumhur İttifakı ve AK Parti adayı İsa Özkan 8.823 oy alarak belediye başkanlığını kazanmıştır. Büyükşehir Belediye Başkanlığ oylamasında Selahattin Gürkan ise Darende ilçesinde 14.538 oy almıştır. Selahattin Gürkan İsa Özkan'dan yaklaşık 5.715 oy fazla almıştır.

2019 yerel seçimlerinde Malatya'da Millet ittifakı üyeleri CHP ve IYYi Parti’nin aday çıkarmadığ 1 iki ilçeden biri olan Darende'de seçim yarışında BBP adayı Hamit Demir 8.542 oy almış ve belediye başkanlığını kazanan İsa Özkan'dan sadece 281 oy geride kalmıştır. BBP Malatya ili Darende ilçesinde Cumhur İttifakının karşısında yer almıştır. Ayrıca istatistiklere göre Millet İttifakı cephesi oylarının önemli bir kısmını aldığı söylenebilir. 
Doğanşehir'de Cumhur İttifakı adayı Vahap Küçük 13.130 oy alarak başkanlığ kazanmıştır. Büyükşehir oylamasında Selahattin Gürkan ise 14.003 oy almış ve Vahap Küçük'ten yaklaşık 873 oy fazla almıştır. Millet İttifakı ve CHP adayı Mehmet Bayram ise ilçede 11.616 oy almıştır. Millet İttifakı Büyükşehir adayına ilçeden 10.355 oy çıkmıştır. Bu sonuca göre yaklaşık 1.350 oyun önemli bir kısmı Cumhur İttifakına geçtiği söylenebilir. Bu sonuçlara göre Doğanşehir ilçesi ittifakların aldığı sonuçlar açısından önem arz eden bir ilçe olmuştur.

Doğanyol ilçesinde Belediye Başkanlığını 1.468 oy alan Cumhur İttifakı ve AK Parti adayı Hakan Bay kazanmıştır. 2014 yerel seçimlerinde Millet Partisi adayı olan ve yarışı kazanamayan Behsat Karakaya, 2019 seçimlerinde Demokrat Parti'den yarışa katılmıştır. Seçimde ikinci olan Behsat Karakaya oyların \%41,93'ü yani 1.172 oy almıştır. Doğanyol ilçesinde de Cumhur İttifakı ve AK Parti büyükşehir adayı Selahattin Gürkan ilçe başkan adayından yaklaşık altı yüzden fazla oy almıştır.

Hekimhan ilçesinde 8.123 oy alan Millet İttifakı ve CHP adayı Turan Karadağ seçimi kazanmıştır. Cumhur İttifakı ve MHP adayı olan H. Mustafa Arıkan ise 7.680 oy almıştır. Hekimhan'da Millet İttifakı adayı Turan Karadağ, büyükşehir adayı Soner Gökçe'den 411 oy fazla almıştır. Diğer yandan Cumhur İttifakı'nın ilçedeki adayı, ittifakın büyükşehir adayından 286 oy az almıştır. Buradan anlaşılacağ partiler ve ittifaklar üzeri bir anlayışılla yaklaşım göstermişlerdir.

Kale ilçesinde Cumhur İttifakı adayı Murat Koca 2.196 oy alarak başkanlığını kazanmıştır. İlçede Demokrat Parti adayı Mehmet Kiraz 1.055 oy almış, BBP adayı Nizamettin Fırat ise 783 oy almıştır. CHP'nin aday göstermediği ilçede Millet İttifakı adayı İYİ Parti'den Adil Geyik ise 16 oy alarak farklı bir sonuçla karşılaşmıştır. Diğer yandan Cumhur İttifakı ilçe adayı, büyükşehir adayından 1.277 oy az almıştır. Bu tabloya göre ilçede DP ve BBP adaylarının etkili olduğu görülmektedir. Diğer yandan ilçedeki bu seçimde aday tercihinin önemi bir kez daha vurgulanmıştır. Şöyle ki, 2014 yılında yapılan yerel seçimlerde AK Parti 2.534 oy ile oyların $\% 66,65$ 'ini almışken (Habertürk, 2014), 2019'da 2.196 oy ile oyların \%53,64'ünü almıştır. Seçimi AK Parti kazanmasına rağmen oylarda yaklaşık \%13 azalma görülmektedir.

Kuluncak ilçesinde Cumhur İttifakı kapsamında MHP adayı Erhan Cengiz 2.778 oy alarak seçimi kazanmıştır. Ancak ilçe adayı Cumhur ittifakı büyükşsehir adayından 1.339 oy az almıştır. Millet ittifakı ve CHP adayı 2.300 oyda kalmıştır. 2014 yerel seçimlerinde Kuluncak ilçesinde Ak Parti 1.520, CHP 1.349, MHP 1.133 oy almış ve seçimi Ak Parti adayı Mehmet Boyraz kazanmıştı. Bu tabloya göre 2019 yerel seçimlerinde Cumhur ittifakı yaklaşık olarak oylarını korumuş görülmektedir. 
2019 yerel seçimlerinde Malatya'da Millet ittifak1 üyeleri CHP ve IYYं Parti'den herhangi birinin aday çıkarmadığ 1 ilçelerden bir olan Pütürge'de, Cumhur İttifakı ve AK Parti adayı olan Mikail Sülük 5.431 oy alarak seçimi kazanmıştır. Saadet Partisi adayı Kasım Tilbaç ise 3.596 oyda kalmıştır. Cumhur ittifakı ve AK Parti adayı seçimi kazanmış olsa da 2014 yerel seçimlerine göre AK Parti' nin oy sayısı yaklaşık 1.500 azalmış ve oy oranı $\% 71,32$ 'den $\% 59,82$ 'ye (Habertürk, 2014) gerilemiştir.

Pütürge'de ilçe oylarından daha fazlasını büyükşehir oylamasında Selahattin Gürkan 1.600 oy gibi bir farkla almıştır. Bu sonuca göre Cumhur İttifakının aday seçimi ve Millet İttifakının aday göstermeden farklı adayları desteklemesi etkili olduğu görülmektedir.

Yazıhan ilçesinde Cumhur ittifakı oylarını artırmış ve önceki belediye başkanı Nevzat Öztürk 6.950 oy alarak belediye başkanlığına yeniden seçilmiştir. Nevzat Öztürk 2014 seçimlerine göre oyunu yaklaşık 2 bin kadar artırmıştır. Buna rağmen Selahattin Gürkan, Nevzat Öztürk'ten yaklaşık beş yüz oy fazla almıştır. Millet ittifakı ve CHP adayı Niyazi Akıncı 3.477 oyda kalmıştır.

\section{Malatya İli 2019 Belediye Meclis Üyeliği Seçim Sonuçları}

Malatya ilinde Belediye Meclis Üyeliği seçimlerinde ilçe belediye başkanlığ seçimlerinden bir anlamda farklılaşan bir tablo ortaya çıkmaktadır. Özellikle Akçadağ ilçesinde ilçe yarışını bağımsız bir adayın kazanması meclis üyeliği dağılımını etkilemiştir.

Tablo 6. Malatya Belediye Meclis Üyelikleri Sonuçları

\begin{tabular}{|c|c|c|c|c|c|c|c|c|c|c|c|c|c|}
\hline İlçe & के & 忩 & $\hat{z}$ & 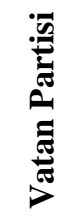 & 苚 & 氕 & 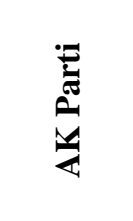 & ิิ & $\underline{\Sigma}$ & & 会 & फิ & 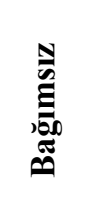 \\
\hline Akçadağ & 386 & 583 & 70 & 0 & 4428 & 7185 & 9289 & 0 & 0 & 0 & 0 & 0 & 1678 \\
\hline Arapgir & 57 & 23 & 23 & 0 & 272 & 3708 & 3056 & 0 & 0 & 0 & 0 & 0 & 0 \\
\hline Arguvan & 25 & 2 & 18 & 0 & 0 & 2862 & 1159 & 0 & 0 & 0 & 539 & 1484 & 0 \\
\hline Battalgazi & 6224 & 393 & 309 & 259 & 3629 & 0 & 110.303 & 0 & 0 & 29.390 & 3594 & 0 & 0 \\
\hline Darende & 208 & 134 & 81 & 0 & 6982 & 0 & 9451 & 0 & 0 & 665 & 0 & 0 & 0 \\
\hline Doğanşehir & 468 & 44 & 99 & 0 & 0 & 11.450 & 12.947 & 0 & 0 & 0 & 0 & 0 & 0 \\
\hline Doğanyol & 35 & 2 & 6 & 0 & 0 & 173 & 1420 & 1131 & 0 & 0 & 0 & 0 & 0 \\
\hline Hekimhan & 164 & 23 & 58 & 0 & 0 & 7946 & 0 & 0 & 7526 & 0 & 0 & 0 & 0 \\
\hline Kale & 34 & 30 & 6 & 0 & 709 & 0 & 2325 & 915 & 0 & 29 & 0 & 0 & 0 \\
\hline Kuluncak & 227 & 68 & 12 & 0 & 621 & 2311 & 0 & 0 & 2781 & 0 & 0 & 23 & 45 \\
\hline Pütürge & 3427 & 37 & 31 & 0 & 0 & 0 & 5530 & 0 & 0 & 0 & 0 & 0 & 0 \\
\hline
\end{tabular}




\begin{tabular}{|c|c|c|c|c|c|c|c|c|c|c|c|c|c|}
\hline Yazıhan & 174 & 19 & 15 & 0 & 0 & 3346 & 6837 & 0 & 0 & 0 & 360 & 0 & 0 \\
\hline Yeşilyurt & 8.159 & 392 & 312 & 160 & 4196 & 35.981 & 101.505 & 495 & 0 & 9145 & 0 & 0 & 0 \\
\hline Toplam & 19.588 & 1750 & 1040 & 419 & 20.837 & 74.962 & 263.822 & 2541 & 10.307 & 39.229 & 4493 & 1507 & 1723 \\
\hline
\end{tabular}

Kaynak: 2019 YSK verilerine göre yazar tarafından derlenmiştir.

Tablo 6'ya göre; Akçadağ ilçesinde bağımsız adayın Belediye Başkanı olması, meclis üyeliğinde AK Parti ve Cumhur İttifakının öne geçmesini engelleyememiş. Akçadağ seçmeni ilçe yerel yöneticisini bağımsız aday olarak tercih etmiş, ancak mecliste Cumhur İttifakı üyelerinin daha fazla yer almasını sağlamıştır.

Darende ilçesinde Millet İttifakı üyelerinden CHP'nin listede olmadığını, IYY İ Parti'nin 665 oy aldığını görmekteyiz. Bu durum ilçede belediye başkan adayı çıkarmayan ve BBP'ye destek veren CHP ve İYİ Parti'nin meclis üyeliğinde ittifak yaptığının bir göstergesi olabilir.

Cumhur İttifakı üyelerinden MHP iki ilçede üyeleri ile katılmış ve Hekimhan'da yaklaşık dört yüz oy ile kaybederken, Kuluncak'ta yaklaşık beş yüz oy ile kazanmıştır.

Millet İttifakı cephesinde üç ilçede CHP kazanmış, İYI Parti dört ilçede katılmış ve hiçbirinde kazanamamıştır. Kale ilçesinde CHP'nin katılmayıp, IYYI Parti'nin 29 oy alabilmesi ilginç sonuçlar arasında yer almaktadır. Pütürge ilçesinde CHP ve IYYİ Parti'nin liste dışında olması ve Saadet Partisi'nin 3.427 oy alması da dikkat çekmiş̧ir. Saadet Partisi'nin ittifakta yer alıp almadı̆̆ 1 konusunda yorumlara neden olmuştur. Resmi ittifakta yer almayan Saadet Partisi'ni ilçede alınan bu sonuçlarla Millet İttifakının yanında değerlendirmek yanlış olabileceği gibi ittifak dışında tutmak da istatistiksel verilere göre pek mümkün değildir.

\section{MART 2019 YEREL SEÇIMLERI MALATYA VE ANKARA SONUÇLARININ KARŞILAŞTIRILMASI}

31 Mart 2019 Yerel Seçimleri Ankara Büyükşehir Belediye Başkanlığı yarışını, CHP ve Millet İttifakı adayı Mansur Yavaş kazanmıştır. 2019 yerel seçimleri, büyükşehir belediye başkanlığı yarışında, Malatya ile Ankara ili seçim sonuçları arasında karşılaş̧ırmalı bir analiz yaparak, yerel seçim sonuçlarının genel seçim sonuçları ile farklılıklarını teyit edebiliriz.

Her seçim döneminin kendine özgü bir yapısının olduğu ve bu sürecin birtakım konjoktürel gelişmelere bağlı olduğu bilinmektedir. 31 Mart seçimlerini bu açıdan değerlendirdiğimizde; Türkiye'de yaşanan ekonomik, sosyal gelişmelerin etkili olduğu görülmektedir. Diğer yandan kurulan resmi ve gayri 
resmi ittifaklar ile adayların ön plana çıkarıldığı bir seçim olmuştur. Ankara ve Malatya bu açıdan karşılaştırma yapılmaya uygun bulunmaktadır.

Tablo 7'de Ankara ili büyükşehir belediye başkanlığı yarışında 25 ilçenin sonuçları yer almaktadır. Bu tabloya göre, ilçelerden büyükşehir belediye başkanı adaylarına verilen oylar ortaya çıkmaktadır. Tablo 8'de ise Ankara'nın ilçelerinde seçime katılan partilerin ilçe belediye başkanlıkları sonucu yer almaktadır. Tablo 7 ve 8 birlikte değerlendirildiğinde; partilerin ilçede aldıkları oylar ile büyükşehir adaylarının aldığ 1 oylar karşılaştırılmıştır. Yapılan karşılaştırmalı analizin detayları paylaşılmıştır.

Resmi veya gayri resmi olarak kurulan ittifakların kesin bir şekilde sonuca ettiği bir il olan Ankara örneği, Malatya ile kıyaslandığında yerel seçimlerin farklı sonuçlar oluşturabileceğini göstermektedir. İlçelerde başarılı veya önde olan parti ilde kazanamamış, ilde başarılı olan ilçeleri kaybetmiş veya istediği oy oranına ulaşamamıştır. Bu sonuçlarda ittifaklara sandıktaki tepkiler, ekonomi ve siyasetin güncel durumları, iç ve dış politikaların seçmende bıraktığı izlenimlerin karşılıkları yer almaktadır.

Ankara'da tüm ilçelerde ve büyükşehirde aday gösteren Saadet Partisi'nin ilçe ve büyükşsehirde aldığı oylar arasındaki fark dikkat çekmektedir. Diğer yandan HDP'nin, Ankara'da 25 ilçenin sadece beşinde aday gösterip, büyükşehirde aday göstermediği dikkat çekmektedir. HDP aday gösterdiği ilçelerde toplamda yaklaşık 18 bin oy almışır.

Ankara ve İstanbul başta olmak üzere çıkan sonuçlar göstermiştir ki; seçmenlerin yerel seçimlerdeki davranışları farklı nedenlere bağlı olarak sandığa yansımaktadır. $\mathrm{Bu}$ nedenle yerel seçim sonuçlarının genel seçim sonuçlarının farklılığı esas alındığında, her iki seçimin karşıllaştırmalı analizi önem taşımaktadır.

Tablo 7. Ankara Büyükşehir Belediye Başkanlık Seçimi Sonucu

\begin{tabular}{|l|l|l|l|l|}
\hline İlçe & SP & CHP & AK Parti & DSP \\
\hline Akyurt & 205 & 4892 & 15.119 & 59 \\
\hline Altındağ & 2456 & 73.930 & 126.706 & 601 \\
\hline Ayaş & 79 & 6098 & 6416 & 24 \\
\hline Bala & 188 & 9831 & 14.690 & 71 \\
\hline Beypazarı & 318 & 15.567 & 15.717 & 60 \\
\hline Çamlıdere & 64 & 2372 & 8760 & 30 \\
\hline Çankaya & 4133 & 437.982 & 121.982 & 1497 \\
\hline Çubuk & 961 & 13.745 & 39.149 & 108 \\
\hline Elmadă̆ & 497 & 14.937 & 13.255 & 64 \\
\hline Etimesgut & 3719 & 185.654 & 143.285 & 1101 \\
\hline
\end{tabular}




\begin{tabular}{|l|l|l|l|l|}
\hline Evren & 17 & 956 & 1662 & 7 \\
\hline Gölbaş1 & 1317 & 35.580 & 38.806 & 203 \\
\hline Güdül & 35 & 2740 & 5080 & 19 \\
\hline Haymana & 1027 & 10.002 & 16.193 & 172 \\
\hline Kahramankazan & 333 & 11.211 & 20.045 & 80 \\
\hline Kalecik & 41 & 3316 & 6032 & 39 \\
\hline Keçiören & 5852 & 231.671 & 282.801 & 1651 \\
\hline Kızılcahamam & 287 & 6848 & 16.706 & 81 \\
\hline Mamak & 3131 & 187.044 & 179.659 & 995 \\
\hline Nallıhan & 144 & 8554 & 10.356 & 95 \\
\hline Polatlı & 675 & 33.784 & 35.516 & 328 \\
\hline Pursaklar & 1130 & 20.362 & 59.066 & 197 \\
\hline Sincan & 3551 & 101.864 & 184.608 & 1184 \\
\hline Şereflikoçhisar & 181 & 8347 & 11.323 & 75 \\
\hline Yenimahalle & 3841 & 234.922 & 165.478 & 965 \\
\hline TOPLAM & $\mathbf{3 4 . 1 8 2}$ & $\mathbf{1 . 6 6 2 . 2 0 9}$ & $\mathbf{1 . 5 3 8 . 4 1 0}$ & $\mathbf{9 7 0 6}$ \\
\hline
\end{tabular}

Kaynak: 2019 YSK verilerine göre yazar tarafından derlenmiştir.

Tablo 7 ve 8'e göre; Ankara'da 25 ilçenin 22'sinde seçimi kazanan Cumhur İttifakı (19 ilçe AK Parti, 3 ilçe MHP) büyükş̧ehirde seçim kazanamamıştır. Diğer yandan Millet İttifakı Ankara'da CHP ile üç belediye başkanlığı kazanmıştır. Ankara'da Millet İttifakının diğer partisi İYİ Parti 25 ilçenin 16'sında aday göstermiş ancak hiçbirini kazanamamıştır. Buradan çıkan başka bir sonuç ise CHP'nin Ankara'da sadece 10 ilçede aday göstermiş olmasıdır. Ankara'da sadece Güdül ilçesinde CHP ve İYİ Parti ittifak yapmamış ve kendi adaylarını göstermişlerdir.

Tablo 8. Ankara İli İlçe Belediye Başkanlıkları Seçimi Sonucu

\begin{tabular}{|l|l|l|l|l|l|}
\hline İlçe & SP & CHP & AK Parti & MHP & İyi Parti \\
\hline Akyurt & 167 & 0 & 11.238 & 0 & 1.461 \\
\hline Altındağ & 5.050 & 0 & 130.434 & 0 & 55.400 \\
\hline Ayaş & 117 & 5.802 & 6.554 & 0 & 0 \\
\hline Bala & 313 & 0 & 15.125 & 0 & 8.766 \\
\hline Beypazarı & 996 & 0 & 15.292 & 0 & 15.179 \\
\hline Çamlıdere & 46 & 0 & 8.229 & 0 & 2.482 \\
\hline Çankaya & 9.023 & 418.740 & 123.222 & 0 & 0 \\
\hline Çubuk & 4.560 & 0 & 35.399 & 0 & 9.408 \\
\hline Elmadağ & 482 & 15.015 & 13.305 & 0 & 0 \\
\hline Etimesgut & 6.116 & 152.057 & 0 & 164.842 & 0 \\
\hline Evren & 9 & 0 & 1.675 & 0 & 918 \\
\hline Gölbaş1 & 2.037 & 0 & 0 & 41.055 & 29.626 \\
\hline Güdül & 33 & 891 & 5.185 & 0 & 1.637 \\
\hline Haymana & 2.297 & 5.966 & 11.903 & 0 & 0 \\
\hline Kahramankazan & 173 & 0 & 17.145 & 0 & 14.483 \\
\hline
\end{tabular}




\begin{tabular}{|l|l|l|l|l|l|}
\hline Kalecik & 33 & 2.928 & 5.739 & 0 & 0 \\
\hline Keçiören & 9.616 & 0 & 332.396 & 0 & 161.336 \\
\hline Kuzılcahamam & 197 & 0 & 14.519 & 0 & 8.928 \\
\hline Mamak & 5.183 & 176.190 & 187.714 & 0 & 0 \\
\hline Nallıhan & 161 & 0 & 10.276 & 0 & 8.501 \\
\hline Polatlı & 670 & 26.809 & 0 & 39.376 & 0 \\
\hline Pursaklar & 1.307 & 0 & 58.567 & 0 & 15.124 \\
\hline Sincan & 6.358 & 0 & 194.879 & 0 & 75.410 \\
\hline Sereflikoçhisar & 265 & 0 & 11.450 & 0 & 7.790 \\
\hline Yenimahalle & 4.422 & 238.187 & 164.156 & 0 & 0 \\
\hline TOPLAM & $\mathbf{5 9 . 6 3 1}$ & $\mathbf{1 . 0 4 2 . 5 8 5}$ & $\mathbf{1 . 3 7 4 . 4 0 2}$ & $\mathbf{2 4 5 . 2 7 3}$ & $\mathbf{4 1 6 . 4 4 9}$ \\
\hline
\end{tabular}

Kaynak: 2019 YSK verilerine göre yazar tarafindan derlenmiştir.

\section{SONUÇ}

Yerel seçimleri genel seçimlerden ayıran en önemli özellik seçimlerde adayların kişisel özelliklerinin ön plana çıkması olarak bilinmektedir. Ayrıca seçmen, genel seçimlerin provası olarak görebilir veya partisine verdiği oylar ile mesaj iletebilir. Ancak değişen sosyal ve siyasal yaşam ile birlikte elde edinilen sonuçlara bakıldığında; kimi yerlerde iktidarda olan parti adayının, kimi yerlerde şehrin güvendiği, kişisel kariyeri ile öne çıkan adayın, kimi yerlerde ise "Genç", "Dinamik" ve "Farklı" gibi sıfatlarla öne çıkan adayların seçimi kazandıkları görülmektedir. Özellikle yerel seçimlerde seçmen davranışları analiz edildiğinde kuramsal yapıların ve teorilerin pratikten farklı olduğu açıkça görülebilmektedir. Bu durum gün geçtikçe siyasal alana ilgi duyan bireylerin ortaya çıkmasına ve siyasal toplumsallaşmanın artmasını sağlamaktadır.

Malatya ilinde 31 Mart 2019 tarihinde yapılan yerel seçimler sonucunun da farklı analizleri yapılabilir. Özellikle Büyükşehir yarışında Cumhur İttifakı'nın Türkiye ikincisi olmasının yanında ilçelerde istediği sonuçları alamaması, Millet İttifakı'nın seçim öncesi beklentilerinin altında kalması ve tüm partilerin çalışmalarının seçmende bıraktığı izlenimler öne çıkmıştır. Şu bir gerçektir ki, söz konusu seçim sonuçlarının, Cumhur İttifakı'na olan güvenden mi, başkan adaylarının kişisel başarılarından $\mathrm{m} 1$, parti içerisinde yaşanılan birtakım gelişmelerin sandığa yansımasından mı olduğu tartışılmaya devam edecektir. Ancak sorunun asıl cevabı elbette seçmende saklıdır.

Seçimlerde çıkan sonuçlara tahammül etmek, seçmen tercihine saygı duymak demokrasinin temel koşullarındandır. $\mathrm{Bu}$ nedenle toplum olarak Malatya seçmeninin ilde ve ilçelerde yapmış olduğu tercihlere saygı duymak gerekliliğini hatırlamak gerekmektedir. Bununla birlikte siyasi partiler ise seçim sonuçlarına bağlı olarak eksiklerini ve hatalarını arama, daha fazla seçmene ulaşabilme hesaplarını yapmaya devam etmektedirler. Partilerin bu çabaları iktidarı ve 
muhalefeti geliştirdiği ve toplumsal sorunların çözümüne odaklandığı sürece anlamlı olacaktır.

\section{KAYNAKÇA}

Ahmad, F. (2012). Modern Türkiye'nin oluşumu. (Çev: Yavuz Alogan). Kaynak Yayınları.

Akgün, B. (2007). Türkiye'de seçmen davranışı, partiler ve siyasal sistem. Nobel Yayınları.

Akıncı, A. ve Usta, S. (2015). Türkiye'de çok partili hayata geçişte etkili olan iç faktörlerin analizi. KMÜ Sosyal ve Ekonomik Araştırmalar Dergisi, 17 (29), 1-52.

Anadolu Ajans1. (AA) (2018, May1s 4). Malatya Büyükşehir Belediye Başkanlı̆̆ı'na Polat seçildi. https://www.aa.com.tr/tr/politika/malatyabuyuksehir-belediye-baskanligina-polat secildi/ 1135413

Büyük Birlik Partisi (BBP). (2019). Cumhur İttifakının zaferiyle seçim sonuçlanacaktır. https://www.bbp.org.tr/haberler/cumhur-ittifakininzaferiyle-secim-sonuclanacaktir-71939

Çam, E. (2002). Siyaset bilimine giriş (8. basım). Der Yayınları.

Demirtaş, M.C. ve Orçun, Ç. (2015). Siyasal pazarlama uygulamalarının ilk kez oy kullanacak seçmenler üzerindeki etkilerine yönelik bir araştırma. $K M U ̈$ Sosyal ve Ekonomik Araştırmalar Dergisi 17 (28), 41- 48.

Doğan, A. ve Göker, G. (2010). Yerel seçimlerde seçmen tercihi (29 Mart yerel seçimleri Elazı̆̆ seçmeni örneği). Eskişehir Osmangazi Üniversitesi İ̈BF Dergisi, 5 (2), 159-187.

Habertürk (2014). HT yerel seçimler 2014. https://www.haberturk.com/secim/secim2014/mahallisecim/sehir/malatya $-44$

Habertürk (2019). Gürkan'dan 31 Mart vurgusu. https://www.haberturk.com/malatya-haberleri/67937245-gurkandan-31mart-vurgusuak-parti-malatya-buyuksehir-adayi-selahattin- gurkan31-marti-secim

Harrop, M. and Miller W. L. (1987). Election and voters a comparative introduction, Mcmillan. 
Sartori, G. (1996). Demokrasi teorisine geri dönüş. (Çev: T. Karamustafaoğlu, ve M. Turhan), Yetkin Yayınları.

Vuslat Haber (2019, Mart 25). Tecrübelerimizi teşmil edeceğiz. http://www.vuslathaber.com/malatya/tecrubelerimizi-tesmil edecegizh39126.html

Yüksek Seçim Kurulu (YSK). (2019). Sandık sonuçları ve tutanaklar. https://sonuc.ysk.gov.tr/sorgu

Zürcher, E. J. (1992). Terakkiperver Cumhuriyet Fırkası. (Çev. Güven, Gül Çağalı). Bağlam Yayıncılık. 